\title{
28 Research Square \\ Effects of regulatory exercise on lipolysis pathway in obese pre and postmenopausal women
}

\section{Kyu-Min Park}

Kangwon National University

\section{Seung-Taek Lim}

Kangwon National University https://orcid.org/0000-0002-0980-991X

\section{Kun-Young Sung}

Kangwon National University Hospital

\section{Sunghwun Kang ( $\sim$ 94psycho@kangwon.ac.kr)}

\section{Research}

Keywords: menopause, obese women, lipolysis, resistance, exercise

Posted Date: June 29th, 2020

DOl: https://doi.org/10.21203/rs.3.rs-37983/v1

License: (c) (1) This work is licensed under a Creative Commons Attribution 4.0 International License. Read Full License 


\section{Abstract}

Background and objectives: The purpose of study was to examine the effects of regulatory resistance exercise for 12 weeks on lipolysis pathway in pre- and post- menopausal women with obesity.

Methods: Twenty-three pre- and post- menopausal women with body fat percentages of $30 \%$ or more divided into pre- menopausal group $(n=9)$ and post- menopausal group $(n=14)$. All subjects participated in resistance exercise training for 12 weeks. All participant's anthropometric measurements and physical fitness tests were performed. Protein analyses were performed with subcutaneous fatty tissue extracted, and the samples were analyzed of relevant protein expression changes by using Western blotting. All serum samples were submitted for enzyme-linked immunosorbent assay measurements of adipocyte factors.

Results: After 12 weeks between pre- menopausal and post- menopausal groups ATGL, MGL and PLIN protein expression were significantly lower in the post- menopausal group than in the pre- menopausal group. HSL protein expression were significantly higher in the post- menopausal group than in the premenopausal group. In addition, leptin concentration was significantly decreased, and adiponectin concentration was significantly increased after resistance exercise in the post- menopausal group more than pre- menopausal group.

Conclusions: In this study indicates that regular resistance exercise to change of leptin and adiponectin might be release of overall decreased ATGL, HSL, MGL and PLIN expression in subcutaneous fatty tissue, and driving reduction of \% fat in the obese post- menopausal group more than obese pre- menopausal group.

\section{Introduction}

Adipose tissue is recognized as regulating various metabolic functions as an endocrine organ. A complex interplay between multiple endocrine mediators and the sympathetic nervous system has been shown to govern adipocyte metabolism. In the postprandial state, insulin promotes glucose and fatty acid uptake as well as lipogenesis and suppresses triglyceride lipolysis [1].

Excess body weight results from an imbalance between energy intake and energy expenditure [2], one way to maintain a correct body weight is to stimulate lipid catabolism through increased physical activity. Appropriately designed training stimulates lipolysis, i.e., the hydrolysis of triacylglycerols stored in adipose tissue, which results in the release of free fatty acids to circulation and their oxidation in muscles and other tissues. Some studies demonstrated that low-intensity endurance training leads to maximal lipid oxidation, but available evidence in this matter is inconclusive [3]. The post-exercise decrease in triacylglycerols content in adipose tissue is with no doubt a consequence of enhanced lipolysis. The process, initiated by adipose triglyceride lipase (ATGL), is then continued by hormone-sensitive lipase (HSL), upon phosphorylation thereof; eventually, the last free fat chain is hydrolyzed by monoacylglycerol lipase (MAGL) [4]. Chronic exercise was shown to normalize the markers of this process, phosphorylated 
HSL and ATGL, in mice that have been previously maintained on a high fat diet [4]. In addition, chronic exercise was shown to stimulate the activity of lipolytic enzymes in the adipocytes of obese mice [5], and a recent study demonstrated that endurance exercise contributed to an increase in triacylglycerol lipase activity in human adipose tissue, especially during the first $10 \mathrm{~min}$ of the training [6]. However, voluntary wheel running for 42 days contributed to a decrease in phosphorylated HSL level in rat [7]. Thus, physical exercise may stimulate lipolytic activity within adipose tissue, that may contribute to more efficient reduction of adipose tissue mass and prevent accumulation thereof. However, there is a lack of research that directly analyzes adipose tissue in humans.

The purpose of this study was to investigate the effects of regulatory exercise for 12 weeks on lipolysis pathway in obese pre and postmenopausal women. In addition, this study aims to provide basic data on the prevention of postmenopausal who may be exposed to obesity or metabolic syndrome.

\section{Materials And Methods}

\section{Subjects}

The subjects of this study were 23 pre and postmenopausal women with body fat percentages of $30 \%$ or more and were divided into PRM (pre- menopausal group, $n=9$ ) and POM (post- menopausal group, $\mathrm{n}=14$ ). The sample size of the subjects was calculated by using ANOVA a large size of effect size of .90, a significance level of .05 and a power of .80 (G*power 3.2.1). All subjects performed a resistance exercise program that consumed 250 300 kcal daily for 12 weeks. To be included in the present study, participants had to meet the following inclusion criteria: 1) postmenopausal (absence of a menstrual cycle for at least 1 year and follicle-stimulating hormone $>30 \mathrm{IU} / \mathrm{L}$ ) ${ }^{8}$ older than 40 (premenopausal) and 50 (postmenopausal) years on the date of the assessment; 3 ) not receiving hormone replacement treatment; and 4) not using drugs such as beta-blockers, and statins. All volunteers underwent medical screening, including a health status interview and physical examination. Written informed consent was obtained from all subjects. The study was approved by Kangwon National University Institutional Review Board (KWNUIRB-2016-04-009-002), and conducted in agreement with the Declaration of Helsinki.

[Table 1. Characteristic of the subjects]

\section{Body composition and physical fitness}

All subjects underwent anthropometric measurements (height, body weight, \% body fat, muscle mass, body mass index [BMI], waist-to-hip ratio [WHR]) using a multi-frequency bioelectrical impedance analyzer with eight tactile electrodes (MF- BIA8) (Inbody 720 body compostion analyzer, Biospace, Seoul, Korea) at the Exercise Physiology Laboratory of Kangwon National University. Bioelectrical impedance analysis was performed after at least $8 \mathrm{~h}$ of fasting and voiding. This analyzer uses an alternating current of $250 \mathrm{~mA}$ at a multi-frequency of $1 \mathrm{kHz}, 5 \mathrm{kHz}, 50 \mathrm{kHz}, 250 \mathrm{kHz}, 500 \mathrm{kHz}$ and 1,000 kHz. It measures segmental impedances at the right arm, left arm, right, leg, left leg and trunk for all frequencies. Total body impedance value was calculated by summing segmental impedance values. 
Physical fitness tests were performed with a circulation measuring device using 02run's Hellmass system 3 (grip strength, sit-ups, sit and reach test, standing long jump, and side step). All measurements were entered into an electronic card and transmitted to the computer. To measure grip strength, subjects stood with both feet at shoulder width and maintained an angle of 15 degrees so that the torso and the arm did not touch each other. They held the handle of the dynamometer with second joints of their fingers and pulled the handle while keeping their arms from shaking. For sit-ups, subjects laid on a mat and bent their knees about 140 degrees. Their feet were flat on the floor. Then the upper body was raised until elbows touched knees. The number of repetitions made in 60 secs was recorded. For sit and reach test, subjects were asked to bend their upper body while fixing the two legs in plate. For standing long jump, all subjects started with their feet in place and jumped as far as possible with the two feet landing together. For side step, parallel lines were drawn at a distance of $120 \mathrm{~cm}$ on the floor and subjects stood on both feet, one foot on the left side and the other foot on the right side, from the center line.

\section{Subcutaneous fatty tissue extracted and Western blot}

All study applicant agreed to extract the abdominal fat.

Plastic surgeon extracts the abdominal fat $30 \mathrm{~g}$ twice before and after exercise program. At first time, right side abdominal fat was extracted. At second time, left side abdominal fat was extracted after exercise program. The applicant lied on the operation bed and plastic surgeon clean the abdomen of applicant with betadine. Plastic surgeon anesthetize the incisional window $(1 \mathrm{~cm}$ length) for liposuction machine tip with $2 \%$ lidocaine. The incisional window was made by no 15 blade and tumescent solution (500cc saline, $2 \%$ lidocaine $5 \mathrm{cc}$ and $0.1 \mathrm{cc}$ epinephrine were mixed) was infiltrated to the around of incisional window. Plastic surgeon extracts the abdominal fat $(30 \mathrm{cc})$ with liposuction machine. The fat was centrifuged during 3 minutes and pure fat cell could be separated. The pure abdominal fat was stored at -18 degrees immediately. The incisional window was sutured with 4-0 nylon and covered the waterproof bandage. The suture materials were removed at 7 postoperative days.

To extract protein from the subcutaneous fatty tissue, the tissues were lysed in $200 \mathrm{ul}$ radioimmunoprecipitation assay (RIPA) buffer. The tissue was homogenized and centrifuged for $30 \mathrm{~min}$ at $14,000 \mathrm{rpm}$. The protein concentration of the supernatant was measured using the BCA protein assay kit (PIERCE, USA). Samples of equal protein content were resolved by SDS-polyacrylaminde gel electrophoresis on a 10 or $12 \%$ gel, and transferred to a membrane. The membrane was blocked with $5 \%$ skim milk in phosphate-buffered saline (PBS), and subsequently incubated at $4^{\circ} \mathrm{C}$ overnight with primary antibodies (1:1,000 dilution) against perilipin (PLIN) (sc-240627), ATGL (adipose triglyceride lipase, sc67355), MGL (monoglyceride lipase, sc-72277), and HSL (hormone-sensitive lipase, sc-25843) (all from Santa Cruz Biotechnology, USA). The signal was developed with an ECL solution (Amersham Pharmacia Biotech, USA) and visualized with the Image Quant TM LAS-4000 system (GE Healthcare, Sweden).

\section{Blood collection and analysis}


Fasting venous blood samples were collected from all participants at baseline, 6-weeks, and 12-weeks. Fasting was maintained for $12 \mathrm{~h}$, and blood samples were collected on the following day. Enough sleep and the radical movement as much as possible to refrain. All samples were taken at $0830 \mathrm{AM}$ from an antecubital vein. Serum samples were obtained after centrifugation and stored at $-80^{\circ} \mathrm{C}$. Serum levels of leptin and adiponectin were measured using enzyme-linked immunosorbent assay Dueset kits (R\&D systems, Minneapolis, MN, USA) according to the manufacturer's instructions, as described previously.

\section{Exercise intervention}

Resistance exercise programs were used following experiments performed by Gurudut and Rajan with slight [8], modifications to fit the purpose of our experiment. The goal of the resistance exercise intervention was to burn 230 260kcal with moderate intensity exercise 60 min per day, 3 days per week for 12 weeks. At the beginning of each session, there was a 10 min of warm-up. It was followed by 40 min of the main part of the exercise with specific content and $10 \mathrm{~min}$ of cool-down. Warm-up exercises included 5 minutes of stretching, and 5 minutes of power walking at $50 \%$ intensity of the maximal heart rate reserve. Among resistance exercises, moderate intensity exercise was defined as circuit exercise at $55 \sim 65 \%$ intensity of $1 \mathrm{RM}, 12$ times of repeat, and 3 sets. The rest period between each category was 30 seconds. The rest period between sets was 1 minute in total resistance exercise time of $60 \mathrm{~min}$. All exercise groups were given a polar (heart rate monitor; M400, Kempele, Finland), a portable exercise intensity setting device, for 60 minutes. Measurement of $1 \mathrm{RM}$ was calculated using formula of Brzycki: $1 \mathrm{RM}=$ Lifted weight $(\mathrm{lb}) /(1.0278$ - repetitions $\times 0.0278)$. All exercises were performed by re-measuring 1RM every two weeks [9].

In addition, dietitians and exercise physiologists met regularly with a clinical health psychologist experienced in lifestyle behavior change to discuss participant progress and refine behavior modification goals according to each participant's needs. Nutritional education, self-management exercise, and behavior change techniques were provided. Furthermore, telephone consultations were scheduled biweekly for monitoring and motivation.

\section{Statistical Analysis}

Data were analyzed using the SPSS 22.0 for Windows computer software package. Data were expressed as mean \pm SD. All the data were tested for their normal distribution using Shapiro-Wilk test. For the two groups (PRM vs. POM) by three stages (baseline, 6 weeks, and 12 weeks), two-way within-subject factor ANOVA was used to examine whether exercise type and time. Bonferroni test was used for post-hoc analysis. A comparison of adipose tissue expression between the groups before and after 12 weeks was analyzed by two-way ANOVA. The main analysis of interest was the analysis of variance interaction term, which compares the change over time between the groups. Statistical significance was accepted at the 0.05 level.

\section{Results}




\section{Change of body composition after exercise}

The change of body composition according to each group is shown in Table 2. Results from two-way within-factor ANOVA showed that main effect of time in weight, BMI, \% fat, WHR, and SBP were statistically significant, However, interaction effect was not significant.

Post-hoc analysis using Bonferroni indicated in the PRM group that significantly decreased 12-weeks than 6-weeks and baseline in weight, \% fat, BMI, WHR, SBP and DBP. And weight, BMI, \% fat and WHR were greater at 12-weeks than 6-weeks and baseline in the POM group.

[Table 2. Change of body composition]

\section{Change of physical fitness after exercise}

The change in physical fitness according to each group is shown in Table 3. Results from two-way withinfactor ANOVA showed that main effect of time in grip strength, sit and reach, sit-up, standing long jump, and side step test were statistically significant, However, interaction effect was not significant.

Post-hoc analysis using Bonferroni indicated in the PRM group that significantly increased 12weeks than 6 weeks and baseline in grip strength, sit and reach, sit-up, and side step test. And left grip strength, sit and reach, sit-up, standing long jump, and side step test were greater at 12-weeks than 6-weeks and baseline in the POM group.

[Table 3. Change of physical fitness]

\section{Change of adipokines after exercise}

The change in adipokines according to each group is shown in Table 4. Results from two-way withinfactor ANOVA showed that main effect of time in leptin and adiponectin were statistically significant, However, interaction effect was not significant.

Post-hoc analysis using Bonferroni indicated in the POM group that significantly decreased 12weeks than 6 weeks and baseline in leptin concentration. And adiponectin concentration was greater at 12-weeks than 6-weeks and baseline in the both groups.

[Table 4. Change of leptin and adiponectin]

\section{ATGL, HSL, MGL and PLIN expression in subcutaneous fatty tissue}

As shown in Figure. 1, ATGL levels in subcutaneous fatty tissue two groups at baseline and post 12 weeks. Within-group analysis showed that the ATGL protein expression was significantly decreased in the post- menopausal group after 12 weeks relative to the baseline values $(-37.15 \%, p<.05)$, but no significant changes was observed in the pre- menopausal group. After 12 weeks between pre- 
menopausal and post- menopausal groups, ATGL protein expression was $42.51 \%$ significantly lower in the post- menopausal group than in the pre- menopausal group.

As shown in Figure. 2, HSL levels in subcutaneous fatty tissue two groups at baseline and post 12weeks. After 12 weeks between pre- menopausal and post- menopausal groups, HSL protein expression was $79.27 \%$ significantly higher in the post- menopausal group than in the pre- menopausal group.

As shown in Figure. 3, MGL levels in subcutaneous fatty tissue two groups at baseline and post 12 weeks. Within-group analysis showed that the MGL protein expression was significantly decreased in the postmenopausal group after 12 weeks relative to the baseline values $(-56.34 \%, p<.001)$, but no significant changes was observed in the pre- menopausal group. After 12 weeks between pre- menopausal and postmenopausal groups, MGL protein expression was $43.21 \%$ significantly lower in the post- menopausal group than in the pre- menopausal group.

As shown in Figure. 4, PLIN levels in subcutaneous fatty tissue two groups at baseline and post 12 weeks. After 12 weeks between pre- menopausal and post- menopausal groups, PLIN protein expression was $27.50 \%$ significantly lower in the post- menopausal group than in the pre- menopausal group.

[Figure 1. ATGL expression baseline and after exercise 12weeks in subcutaneous fatty tissue]

[Figure 2. HSL expression baseline and after exercise 12weeks in subcutaneous fatty tissue]

[Figure 3. MGL expression baseline and after exercise 12 weeks in subcutaneous fatty tissue]

[Figure 4. PLIN expression baseline and after exercise 12 weeks in subcutaneous fatty tissue]

\section{Discussion}

In this study, examine the effect of regulatory resistance exercise on lipolysis pathway in pre-and postmenopausal women. The main finding of this study after 12 weeks between pre-menopausal and postmenopausal groups ATGL, MGL and PLIN protein expression were lower by $42.51 \%, 43.21 \%$ and $27.50 \%$, HSL protein expression was higher by $79.27 \%$ in the post- menopausal group than in the pre- menopausal group. In addition, leptin concentration was significantly decreased after resistance exercise both groups, and adiponectin concentration was significantly increased after resistance exercise both groups. In physical fitness, grip strength, sit and reach, sit-up and standing long jump were significantly increased after exercise both groups.

The postmenopausal women have higher intramuscular fat and subcutaneous adipose tissue compared to men and premenopausal women, in the activity of key enzymes involved in free fatty acid (FFA) metabolism between pre- and post- menopausal women [10]. The relationship of FFA release to the amount of body fat that originating from the release of adipose tissue triglyceride fatty acid, represent virtually the only route by which these fat stores can be transferred to nonfat tissue for net loss via oxidation [11]. Triacylglycerol and diacylglycerol are broken down by the lipases ATGL and HSL which 
fasting lipolysis, expressed per unit fat mass, may be decreased in obese subjects [12]. Diacylglycerol is converted to monoacylglycerol and a second fatty acid by the action of HSL, after that, MGL hydrolyses monoacylglycerol, producing glycerol and a last fatty acid [13]. Besides protein perilipin (PLIN) which is thought to modulate the accession of HSL to the surface of the fat droplet [14], that plays a major role in lipogenesis by regulating the function of lipases [15]. In this study, we observed changes lipolysis related lipase such as ATGL, HSL, MGL, and PLIN after 12 weeks of resistance exercise in obese females who pre- and post- menopausal. As the results that ATGL and MGL expression were $37.15 \%$ and $56.34 \%$ significantly decreased after 12 weeks of resistance exercise in post- menopausal group. Estrogen and estrogen receptor alpha are known to repress intra-abdominal adipose formation [16]. Wend et al. reported that lipid droplet size (relative area per lipid droplet) and the number of lipid droplets per cell were measured in estrogen receptor alpha knockout (ERaKO) which postmenopausal model mice, as the results ATGL expression and lipid droplet size were significantly reduced in ERaKO cells compared to wild-type model mice [17]. It is mean that ERaKO mice develop more adipose tissue in the perirenal, periovarian, and mesenteric/omental regions than wild-type model mice [18]. Walhin et al. reported that down-regulated HSL by a period of positive energy balance and up-regulated HSL by a period of negative energy balance in this study [19]. However, other studies reported that activation of lipolysis occurred through increase of ATGL, HSL, and MGL expression and glycerol release [20]. And activities of ATGL, HSL and MGL were significantly higher in the diet and exercise mice group than the high fat diet mice group [5]. In this study results ATGL and MGL expression were significantly decreased after 12 weeks of resistance exercise. HSL and PLIN expression were tend to decreased after 12 weeks of resistance exercise in post- menopausal group more than pre- menopausal group which similar to Wend et al. and Walhin et al $[17,18]$. Because, significantly decreased body weight and $\%$ fat after 12 weeks of resistance exercise, thus might be reduced total adipose tissue. In additional, a greater decreased of lipolysis factors in post- menopausal group seems to have a resistance exercise effect more than the pre-menopausal group.

Furthermore, significantly decreased 12 weeks than 6 weeks and baseline in leptin concentration and adiponectin concentration were greater at 12 weeks than 6 weeks and baseline in the post- menopausal group more than pre- menopausal group which these results were supported that lipolysis of ATGL, HSL, MGL and PLIN expression in the study. Adipose tissue revealed that not only free fatty acids, the product of lipolysis, but also several polypeptides are released from the adipocyte, also known as adipocytokines, leptin and adiponectin are currently the most prominent ones [21]. Adiponectin is an adipocyte-derived hormone that sensitizes insulin and improves energy metabolism in tissues [22]. In this regard, adiponectin is relatively unique as an adipokine because it is expressed at highest levels in lean and healthy individuals [23]. Several studies reported about effects of resistance exercise on women. Park et al. shown that significant differences in leptin and adiponectin levels in pre- and post- menopausal women after 12 weeks of resistance exercise [24]. Dieli-Conwright et al. shown that leptin, adiponectin, and body mass index were significantly improved after 16 weeks of aerobic and resistance exercise in overweight or obese survivors of breast cancer [25]. Rosety-Rodriguez et al. reported that leptin level was significantly decreased after the completion of the resistance circuit training [26]. Above previous studies, 
regular resistance exercise improved leptin and adiponectin levels in both groups with decrease of body fat percentage. Dysregulation of concentration levels of adipokines (leptin and adiponectin), lipolysis lipase (ATGL, HSL, MGL) and perilipin (PLIN) in cholesterol-induced inflamed adipose tissue contributed to increased lipolysis and increased circulating nonesterified fatty acids [27]. In this study, regular resistance exercise might be decreased leptin, body weight, \% fat, and increased adiponectin levels. This reason why reduced total adipose tissue supported by decreased ATGL, HSL, MGL and PLIN expression in subcutaneous fatty tissue after 12 weeks' resistance exercise.

Resistance exercise is well-known improve body composition in obese adults [28]. In additional, resistance exercise increasing fat free mass and decreasing body weight in pre-and post- menopausal with obesity $[29,30]$. In this study observed that body weight, body mass index, \% fat, waist-to-hip ratio were significantly decreased after 12-weeks than 6-weeks resistance exercise in both groups. Although, did not significantly in muscle mass but tended to increased. Even though, significantly improvement of grip strength, sit and reach, sit-up, and side step test after 12-weeks than 6-weeks resistance exercise in both groups. Weight gain and obesity largely drives the increased prevalence of metabolic syndrome in pre- and post- menopausal women [31]. Because of the associated sequelae of coronary heart disease, cardiovascular disease, diabetes, and mortality, life style management should be of paramount importance in obese women.

Finally, in this study meaningful to directly analyzes adipose tissue in humans, however the present study has some limitations. The sample size was relatively small, and further studies with larger populations are required to validate our findings. Another limitation is that to determine whether there is a gender and age difference in lipolysis factors. Also, we did not control for confounding factors such as food energy intake and habitual activity, confounding factors should be considered in future studies.

\section{Conclusion}

In conclusion, this study indicates that regular resistance exercise to change of lipolysis factors (ATGL, HSL, MGL and PLIN) of subcutaneous fatty tissue, and adipokines (leptin and adiponectin) of serum in the post- menopausal group more than pre- menopausal group. Moreover, improvement of body composition and physical fitness in obese pre- and post- menopausal women. The positive change leptin and adiponectin might be release of overall decreased ATGL, HSL, MGL and PLIN expression in subcutaneous fatty tissue, and driving reduction of $\%$ fat in the obese post- menopausal group more than obese pre- menopausal group.

\section{Abbreviation}

ATGL: adipose triglyceride lipase; BMI: body mass index; DBP: diastolic blood pressure; FFA: free fatty acid; HSL: hormone-sensitive lipase; MAGL: monoacylglycerol lipase; PLIN: perilipin; POM: postmenopausal; PRM: pre- menopausal; RM: repetition maximum; SBP: systolic blood pressure; WHR: waistto-hip ratio 


\section{Declarations}

\section{Acknowledgments}

This work was supported by the Ministry of Education of the Republic of Korea and the National Research Foundation of Korea (NRF-2016R1D1A1B03930331).

\section{Authors' contributions}

Kyu-Min Park, Seung-Taek Lim, and Sunghwun Kang contributed to conception and design of the study.

Kyu-Min Park, Seung-Taek Lim, and Kun-Young Sung implemented the measurements and training sessions. Kun-Young Sung analysed the participant data. All authors interpreted and discussed the results. All authors drafted parts of the manuscript. All authors read and approved the final manuscript.

\section{Funding}

Not applicable

\section{Availability of data and materials}

The datasets analysed during the current study are available from the corresponding author on reasonable request.

\section{Ethics approval and consent to participate}

The study was approved by Kangwon National University Institutional Review Board, and conducted in agreement with the Declaration of Helsinki. In advance of their participation, all of the participants were fully informed about the purpose and experimental procedures of the study. All of the participants completed consent forms. The participants were informed that all data collected would be processed anonymously.

\section{Consent for publication}

All participants provided consent for publishing their data anonymously.

\section{Competing interests}

All authors declare that they have no competing interest

\section{Author details}

1. Laboratory of Exercise Physiology, Department of Sport Science, College of Art, Culture and Engineering, Kangwon National University, Gangwon-do, Republic of Korea. 2. Institute of Sport Science, Kangwon National University, Gangwon-do, Republic of Korea. 3. Waseda Institute for Sport Sciences, Waseda University, Saitama, Japan. 4. Nasaret International Hospital, Incheon, Republic of 
Korea. 5. Department of Plastic and Reconstructive Surgery, College of Medicine, Kangwon National University Hospital, Kangwon National University, Gangwon-do, Republic of Korea.

\section{References}

1. Samuel VT, Shulman GI. Mechanisms for insulin resistance: common threads and missing links. Cell. 2012;148:852-71. https://doi.org/10.1016/j.cell.2012.02.017

2. Jakicic JM, Otto AD. Physical activity considerations for the treatment and prevention of obesity. Am J Clin Nutr. 2005;82:226S-9S. https://doi.org/10.1093/ajcn/82.1.226S

3. Romain AJ, Carayol M, Desplan M, Fedou C, Ninot G, Mercier J, Avignon A, Brun JF. Physical activity targeted at maximal lipid oxidation: a meta-analysis. J Nutr Metab. 2012;2012:285395. https://doi.org/10.1155/2012/285395

4. Chen N, Cheng J, Zhou L, Lei T, Chen L, Shen Q, Qin L, Wan Z. Effects of treadmill running and rutin on lipolytic signaling pathways and TRPV4 protein expression in the adipose tissue of diet-induced obese mice. J Physiol Biochem. 2015;71:733-42. https://doi.org/10.1007/s13105-015-0437-5

5 . Woo J, Kang S. Diet change and exercise enhance protein expression of CREB, CRTC 2 and lipolitic enzymes in adipocytes of obese mice. Lipids Health Dis. 2016;15:147.

https://doi.org/10.1186/s12944-016-0316-2

6. Petridou A, Chatzinikolaou A, Avloniti A, Jamurtas A, Loules G, Papassotiriou I, Fatouros I, Mougios V. Increased Triacylglycerol Lipase Activity in Adipose Tissue of Lean and Obese Men During Endurance Exercise. J Clin Endocrinol Metab. 2017;102:3945-52. https://doi.org/10.1210/jc.201700168

7. Holland AM, Kephart WC, Mumford PW, Mobley CB, Lowery RP, Shake JJ, Patel RK, Healy JC, McCullough DJ, Kluess HA, et al. Effects of a ketogenic diet on adipose tissue, liver, and serum biomarkers in sedentary rats and rats that exercised via resisted voluntary wheel running. Am J Physiol Regul Integr Comp Physiol. 2016;311:R337-51. https://doi.org/10.1152/ajpregu.00156.2016

8. Gurudut P, Rajan AP. Immediate effect of passive static stretching versus resistance exercises on postprandial blood sugar levels in type 2 diabetes mellitus: a randomized clinical trial. J Exerc Rehabil. 2017;13:581-7. https://doi.org/10.12965/jer.1735032.516

9. Brzycki M. Strength testing: predicting a one-rep max from a reps-to-fatigue. Journal of physical education, recreation \& dance. 1993;64:88-90. https://doi.org/10.1080/07303084.1993.10606684

10. Ortmeyer HK, Goldberg AP, Ryan AS. Exercise with weight loss improves adipose tissue and skeletal muscle markers of fatty acid metabolism in postmenopausal women. Obesity (Silver Spring). 2017;25:1246-53. https://doi.org/10.1002/oby.21877

11. Jensen MD, Haymond MW, Rizza RA, Cryer PE, Miles JM. Influence of body fat distribution on free fatty acid metabolism in obesity. J Clin Invest. 1989;83:1168-73. https://doi.org/10.1172/JCI113997

12. Stinkens R, Goossens GH, Jocken JW, Blaak EE. Targeting fatty acid metabolism to improve glucose metabolism. Obes Rev. 2015;16:715-57. https://doi.org/10.1111/obr.12298 
13. Bolsoni-Lopes A, Alonso-Vale MI. Lipolysis and lipases in white adipose tissue - An update. Arch Endocrinol Metab. 2015;59:335-42. https://doi.org/10.1590/2359-3997000000067

14. Souza SC, de Vargas LM, Yamamoto MT, Lien P, Franciosa MD, Moss LG, Greenberg AS. Overexpression of perilipin $A$ and $B$ blocks the ability of tumor necrosis factor alpha to increase lipolysis in 3T3-L1 adipocytes. J Biol Chem. 1998;273:24665-9. https://doi.org/10.1074/jbc.273.38.24665

15. Zimmermann R, Lass A, Haemmerle G, Zechner R. Fate of fat: the role of adipose triglyceride lipase in lipolysis. Biochim Biophys Acta. 2009;1791:494-500. https://doi.org/10.1016/j.bbalip.2008.10.005

16. Santos RS, Frank AP, Fátima LA, Palmer BF, Öz OK, Clegg DJ. Activation of estrogen receptor alpha induces beiging of adipocytes. Mol Metab. 2018;18:51-9.

https://doi.org/10.1016/j.molmet.2018.09.002

17. Wend K, Wend P, Drew BG, Hevener AL, Miranda-Carboni GA, Krum SA. ERa regulates lipid metabolism in bone through ATGL and perilipin. J Cell Biochem 2013;114:1306-14. https://doi.org/10.1002/jcb.24470

18. Ohlsson C, Hellberg N, Parini P, Vidal O, Bohlooly-Y M, Rudling M, Lindberg MK, Warner M, Angelin B, Gustafsson JA. Obesity and disturbed lipoprotein profile in estrogen receptor-alpha-deficient male mice. Biochem Biophys Res Commun. 2000;278:640-5. https://doi.org/10.1006/bbrc.2000.3827

19. Walhin JP, Dixon NC, Betts JA, Thompson D. The impact of exercise intensity on whole body and adipose tissue metabolism during energy restriction in sedentary overweight men and postmenopausal women. Physiol Rep. 2016;4:e13026. https://doi.org/10.14814/phy2.13026

20. Lo Furno D, Graziano AC, Avola R, Giuffrida R, Perciavalle V, Bonina F, Mannino G, Cardile V. A Citrus bergamia Extract Decreases Adipogenesis and Increases Lipolysis by Modulating PPAR Levels in Mesenchymal Stem Cells from Human Adipose Tissue. PPAR Res. 2016;2016:4563815. https://doi.org/10.1155/2016/4563815

21. Staiger H, Tschritter O, Machann J, Thamer C, Fritsche A, Maerker E, Schick F, Häring HU, Stumvoll M. Relationship of serum adiponectin and leptin concentrations with body fat distribution in humans. Obes Res. 2003;11:368-72. https://doi.org/10.1038/oby.2003.48

22. Qiao L, Kinney B, Schaack J, Shao J. Adiponectin inhibits lipolysis in mouse adipocytes. Diabetes. 2011;60:1519-27. https://doi.org/10.2337/db10-1017

23. Walsh K. Adipokines, myokines and cardiovascular disease. Circ J. 2009;73:13-8. https://doi.org/10.1253/circj.cj-08-0961

24. Park KM, Park SC, Kang S. Effects of resistance exercise on adipokine factors and body composition in pre- and postmenopausal women. J Exerc Rehabil. 2019;15:676-82. https://doi.org/10.12965/jer.1938368.184

25. Dieli-Conwright CM, Courneya KS, Demark-Wahnefried W, Sami N, Lee K, Buchanan TA, Spicer DV, Tripathy D, Bernstein L, Mortimer JE. Effects of Aerobic and Resistance Exercise on Metabolic Syndrome, Sarcopenic Obesity, and Circulating Biomarkers in Overweight or Obese Survivors of 
Breast Cancer: A Randomized Controlled Trial. J Clin Oncol. 2018;36:875-83.

https://doi.org/10.1200/JC0.2017.75.7526

26. Rosety-Rodriguez M, Camacho A, Rosety I, Fornieles G, Rosety MA, Diaz AJ, Rosety M, Ordonez FJ. Resistance circuit training reduced inflammatory cytokines in a cohort of male adults with Down syndrome. Med Sci Monit. 2013;19:949-53. https://doi.org/10.12659/MSM.889362

27. Huang JP, Hsu SC, Meir YJ, Hsieh PS, Chang CC, Chen KH, Chen JK, Hung LM. Role of dysfunctional adipocytes in cholesterol-induced nonobese metabolic syndrome. J Mol Endocrinol. 2018;60:307-21. https://doi.org/10.1530/JME-17-0194

28. Villareal DT, Aguirre L, Gurney AB, Waters DL, Sinacore DR, Colombo E, Armamento-Villareal R, Qualls C. Aerobic or Resistance Exercise, or Both, in Dieting Obese Older Adults. N Engl J Med. 2017;376:1943-55. https://doi.org/10.1056/NEJMoa1616338

29. Cunha PM, Ribeiro AS, Tomeleri CM, Schoenfeld BJ, Silva AM, Souza MF, Nascimento MA, Sardinha LB, Cyrino ES. The effects of resistance training volume on osteosarcopenic obesity in older women. J Sports Sci. 2018;36:1564-71. https://doi.org/10.1080/02640414.2017.1403413

30. Ahn N, Kim HS, Kim K. Exercise training-induced changes in metabolic syndrome parameters, carotid wall thickness, and thyroid function in middle-aged women with subclinical hypothyroidism. Pflugers Arch. 2019;471:479-89. https://doi.org/10.1007/s00424-019-02254-7

31. Lobo RA. Metabolic syndrome after menopause and the role of hormones. Maturitas. 2008;60:10-8. https://doi.org/10.1016/j.maturitas.2008.02.008

\section{Tables}

\begin{tabular}{|lll|}
\hline \multicolumn{3}{|l|}{ Table 1. Characteristic of subjects } \\
Variable & Group & Mean \pm SD (range) \\
\hline Age (year) & PRM & $44.44 \pm 3.50(41-47)$ \\
\cline { 2 - 3 } & POM & $60.50 \pm 6.12(56-64)$ \\
\hline Height (cm) & PRM & $158.71 \pm 5.28(154-167)$ \\
\cline { 2 - 3 } & POM & $155.95 \pm 3.48(151-164)$ \\
\hline Weight (kg) & PRM & $66.90 \pm 13.40(48-83)$ \\
\cline { 2 - 3 } & POM & $61.81 \pm 6.51(50-72)$ \\
\hline Fat (\%) & PRM & $36.98 \pm 7.41(31-42)$ \\
\cline { 2 - 3 } & POM & $35.04 \pm 5.59(31-38)$ \\
\hline Mean $\pm S D$ & & \\
PRM; premenopausal, POM; postmenopausal \\
\hline
\end{tabular}


Page 14/21 


\begin{tabular}{|c|c|c|c|c|c|c|}
\hline variable & & Oweek & 6weeks & 12 weeks & Source & $\mathrm{F}(p)$ \\
\hline \multirow[t]{3}{*}{ Weight (kg) } & \multirow[t]{2}{*}{ PRM } & \multirow[t]{2}{*}{$66.90 \pm 13.40^{\mathrm{a}}$} & \multirow[t]{2}{*}{$66.47 \pm 12.83$} & \multirow[t]{2}{*}{$64.46 \pm 11.73^{c}$} & \multirow{3}{*}{$\begin{array}{l}G \\
T \\
G \times T\end{array}$} & $\begin{array}{l}1.513 \\
(.232)\end{array}$ \\
\hline & & & & & & $\begin{array}{l}10.692 \\
(.001)\end{array}$ \\
\hline & POM & $61.81 \pm 6.51^{\mathrm{a}}$ & $60.98 \pm 6.14^{b}$ & $60.65 \pm 5.68$ & & $\begin{array}{l}2.463 \\
(.097)\end{array}$ \\
\hline \multirow[t]{3}{*}{ BMI $\left(\mathrm{kg} / \mathrm{m}^{2}\right)$} & \multirow[t]{2}{*}{ PRM } & \multirow[t]{2}{*}{$26.36 \pm 4.29$} & \multirow[t]{2}{*}{$26.33 \pm 4.40$} & \multirow[t]{2}{*}{$25.46 \pm 3.74^{c}$} & \multirow{3}{*}{$\begin{array}{l}G \\
T \\
G \times T\end{array}$} & $\begin{array}{c}0.392 \\
(.538)\end{array}$ \\
\hline & & & & & & $\begin{array}{l}10.606 \\
(.000)\end{array}$ \\
\hline & POM & $25.49 \pm 2.69^{a}$ & $25.10 \pm 2.56^{b}$ & $24.96 \pm 2.44$ & & $\begin{array}{l}2.624 \\
(.084)\end{array}$ \\
\hline \multirow[t]{4}{*}{ Muscle (kg) } & \multirow[t]{2}{*}{ PRM } & \multirow[t]{2}{*}{$22.72 \pm 4.10$} & \multirow[t]{2}{*}{$23.16 \pm 4.03$} & \multirow[t]{2}{*}{$23.26 \pm 4.22$} & \multirow{4}{*}{$\begin{array}{l}G \\
T \\
G \times T\end{array}$} & $\begin{array}{l}0.884 \\
(.358)\end{array}$ \\
\hline & & & & & & 2.144 \\
\hline & \multirow[t]{2}{*}{ POM } & \multirow[t]{2}{*}{$21.68 \pm 1.95$} & \multirow[t]{2}{*}{$22.10 \pm 2.06$} & \multirow[t]{2}{*}{$21.86 \pm 1.87$} & & $(.130)$ \\
\hline & & & & & & $\begin{array}{c}0.438 \\
(.619)\end{array}$ \\
\hline \multirow[t]{4}{*}{ Fat (\%) } & \multirow[t]{2}{*}{ PRM } & \multirow[t]{2}{*}{$36.98 \pm 7.41^{a}$} & \multirow[t]{2}{*}{$35.48 \pm 7.08^{b}$} & $33.57 \pm 6.49$ & & $\begin{array}{c}0.407 \\
(.530)\end{array}$ \\
\hline & & & & & 1 & 10.719 \\
\hline & POM & $35.04 \pm 5.59^{a}$ & $32.87 \pm 6.03^{b}$ & $33.20 \pm 5.37$ & $\mathrm{G} \times \mathrm{T}$ & $(.000)$ \\
\hline & & & & & & $\begin{array}{l}1.958 \\
(.155)\end{array}$ \\
\hline WHR & PRM & $0.93 \pm 0.06^{a}$ & $0.92 \pm 0.06^{b}$ & $0.90 \pm 0.05^{c}$ & & $\begin{array}{l}3.133 \\
(.091)\end{array}$ \\
\hline & & & & & & 14.601 \\
\hline & POM & $0.90 \pm 0.04^{\mathrm{a}}$ & $0.87 \pm 0.04^{b}$ & $0.88 \pm 0.03$ & GxT & $(.000)$ \\
\hline & & & & & & $\begin{array}{l}1.855 \\
(.168)\end{array}$ \\
\hline $\begin{array}{l}\text { SBP } \\
(\mathrm{mmHg})\end{array}$ & PRM & $132.44 \pm 17.56^{\mathrm{a}}$ & $126.44 \pm 13.28$ & $115.78 \pm 12.16^{c}$ & G & $\begin{array}{l}3.565 \\
(.073)\end{array}$ \\
\hline & & & & & & 8.754 \\
\hline & POM & $139.00 \pm 15.63$ & $135.79 \pm 14.85$ & $131.43 \pm 16.49$ & GXI & \\
\hline & & & & & & $\begin{array}{l}1.270 \\
(.291)\end{array}$ \\
\hline DBP & PRM & $81.00 \pm 6.86^{a}$ & $82.67 \pm 7.45$ & $76.22 \pm 7.64^{c}$ & G & 2.585 \\
\hline
\end{tabular}


Mean $\pm S D$,

PRM; premenopausal, POM; postmenopausal, BMI; body mass index, WHR; waist-to-hip ratio, SBP; systolic blood pressure, DBP; diastolic blood pressure, G; Group, T; Time, G×T; GroupxTime post-hoc: a: Oweek vs. 12 weeks; b: 0week vs. 6 weeks; c: 6 weeks vs. 12 weeks 


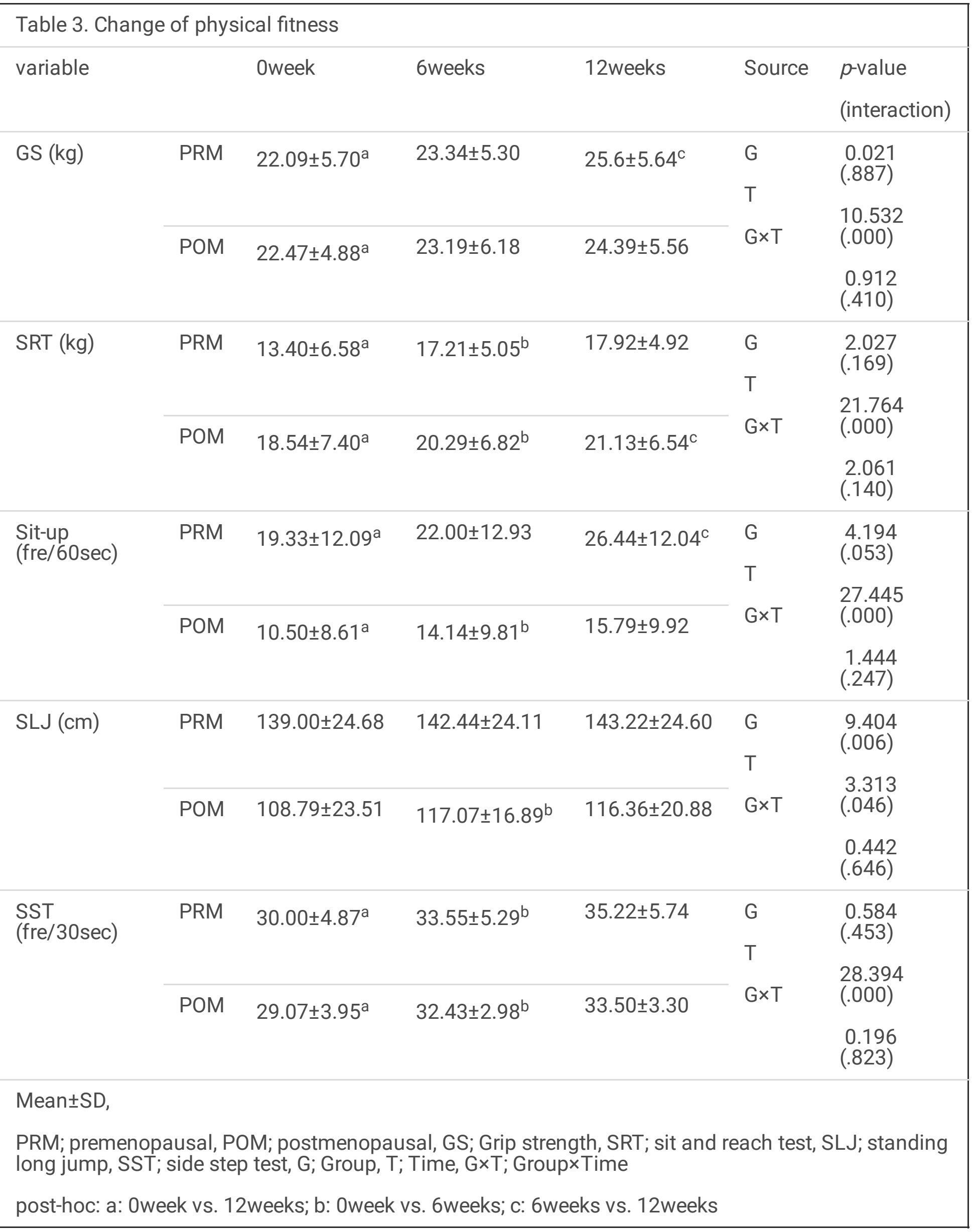




\begin{tabular}{|c|c|c|c|c|c|c|}
\hline variable & & Oweek & 6weeks & 12 weeks & Source & $\begin{array}{l}p \text {-value } \\
\text { (interaction) }\end{array}$ \\
\hline \multirow[t]{3}{*}{ Leptin (pg/ml) } & PRM & $386.2 \pm 103.9$ & $347.7 \pm 116.1$ & $293.6 \pm 155.1$ & \multirow{3}{*}{$\begin{array}{l}\mathrm{G} \\
\mathrm{T} \\
\mathrm{G} \times \mathrm{T}\end{array}$} & \multirow{2}{*}{$\begin{array}{c}0.519 \\
(.479) \\
7.022 \\
(.002)\end{array}$} \\
\hline & \multirow[t]{2}{*}{ POM } & \multirow{2}{*}{$368.1 \pm 73.9^{a}$} & \multirow{2}{*}{$304.0 \pm 87.7^{b}$} & \multirow{2}{*}{$281.7 \pm 91.7$} & & \\
\hline & & & & & & $\begin{array}{l}0.247 \\
(.782)\end{array}$ \\
\hline \multirow[t]{3}{*}{$\begin{array}{l}\text { Adiponectin } \\
(\mathrm{pg} / \mathrm{ml})\end{array}$} & \multirow[t]{2}{*}{ PRM } & \multirow[t]{2}{*}{$59.04 \pm 4.78^{a}$} & \multirow[t]{2}{*}{$62.99 \pm 5.88^{b}$} & \multirow[t]{2}{*}{$66.38 \pm 5.51^{c}$} & \multirow{3}{*}{$\begin{array}{l}G \\
T \\
G \times T\end{array}$} & \multirow{2}{*}{$\begin{array}{l}0.117 \\
(.736) \\
53.389 \\
(.000)\end{array}$} \\
\hline & & & & & & \\
\hline & POM & $58.98 \pm 3.06^{\mathrm{a}}$ & $62.60 \pm 4.75^{b}$ & $68.80 \pm 6.04^{\mathrm{c}}$ & & $\begin{array}{l}(.000) \\
1.710 \\
(.193)\end{array}$ \\
\hline \multicolumn{7}{|c|}{ Mean $\pm S D$} \\
\hline \multicolumn{7}{|c|}{$\begin{array}{l}\text { PRM; premenopausal, POM; postmenopausal, G; Group, T; Time, G×T; Group×Time } \\
\text { post-hoc: a: 0week vs. } 12 \text { weeks; b: 0week vs. } 6 \text { weeks; c: } 6 \text { weeks vs. } 12 \text { weeks }\end{array}$} \\
\hline
\end{tabular}

\section{Figures}



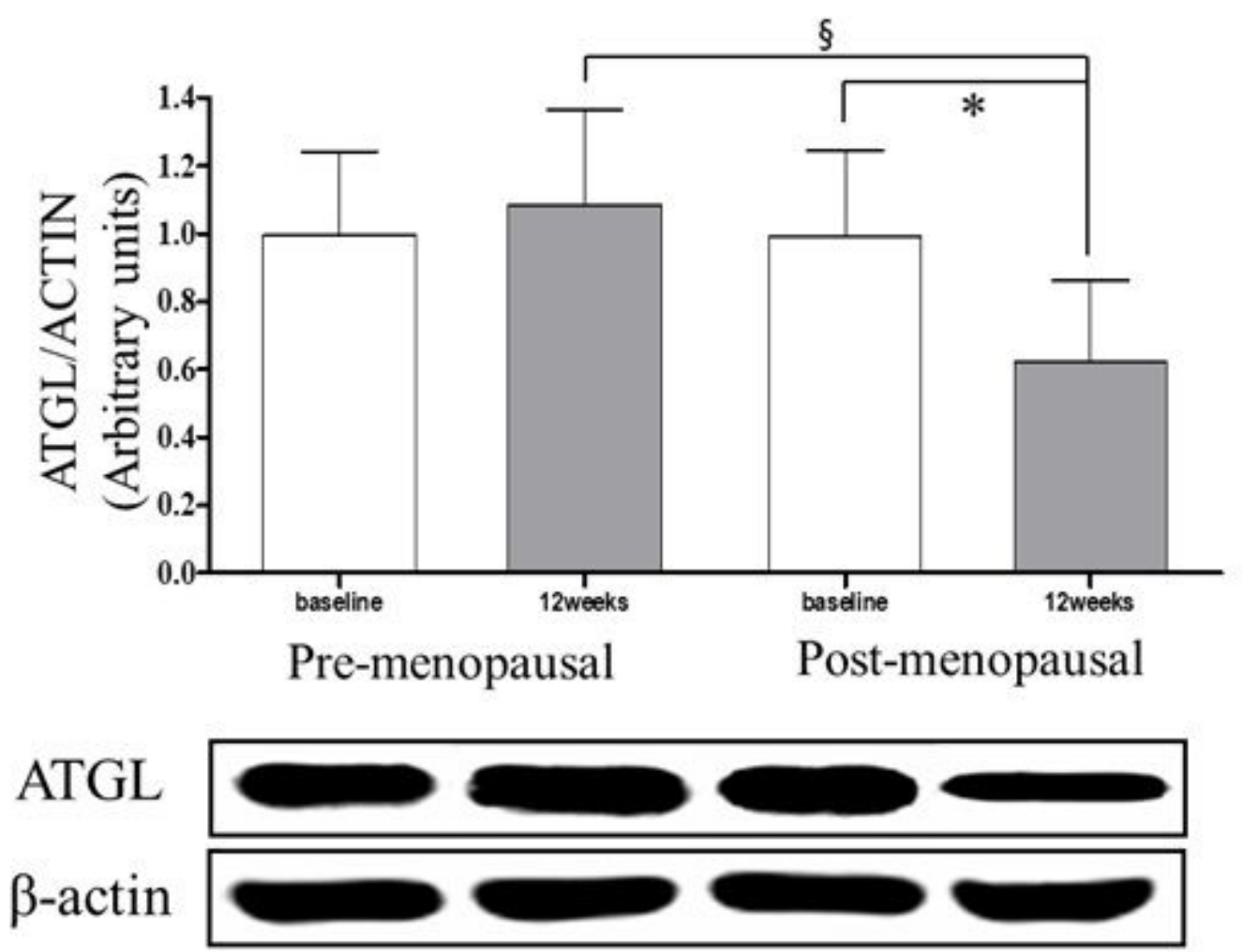

Figure 1

ATGL expression baseline and after exercise 12 weeks in adipose tissue * $p<0.05$, significantly different from baseline in the within group $\S p<0.05$, significantly different from 12 weeks in the each groups

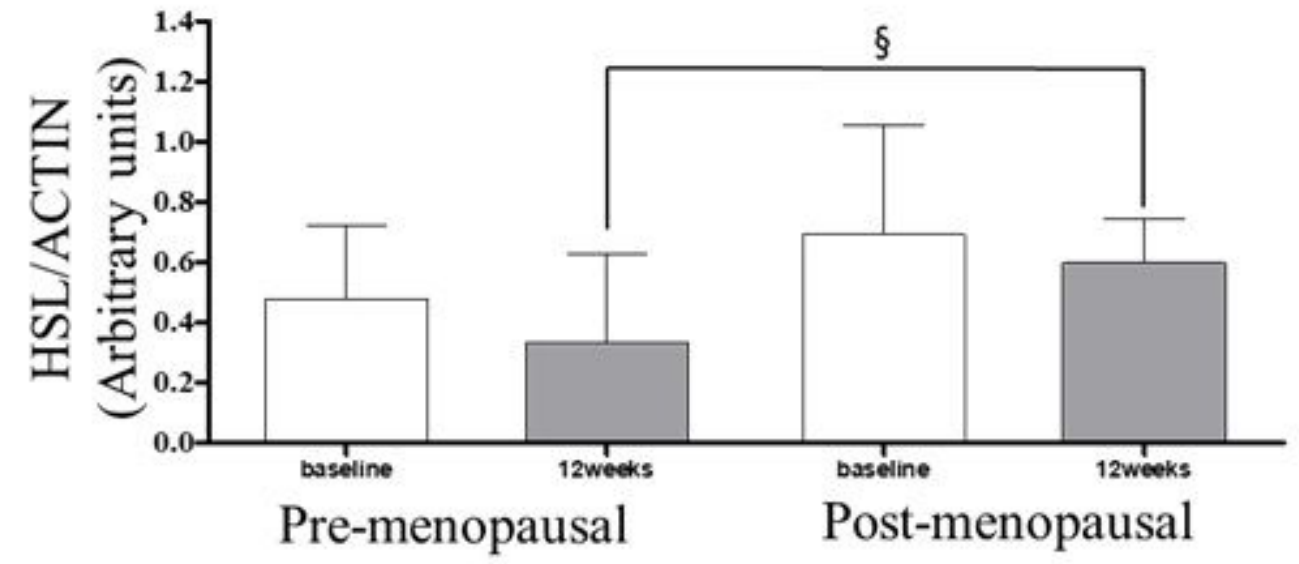

HSL

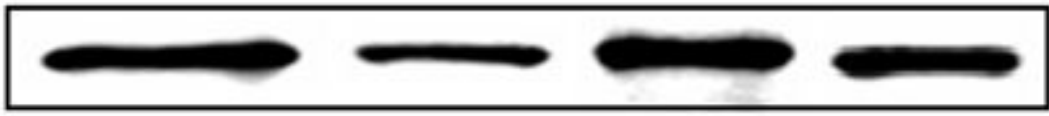

$\beta$-actin

Figure 2 
HSL expression baseline and after exercise 12 weeks in adipose tissue $\S p<0.05$, significantly different from 12 weeks in the each groups
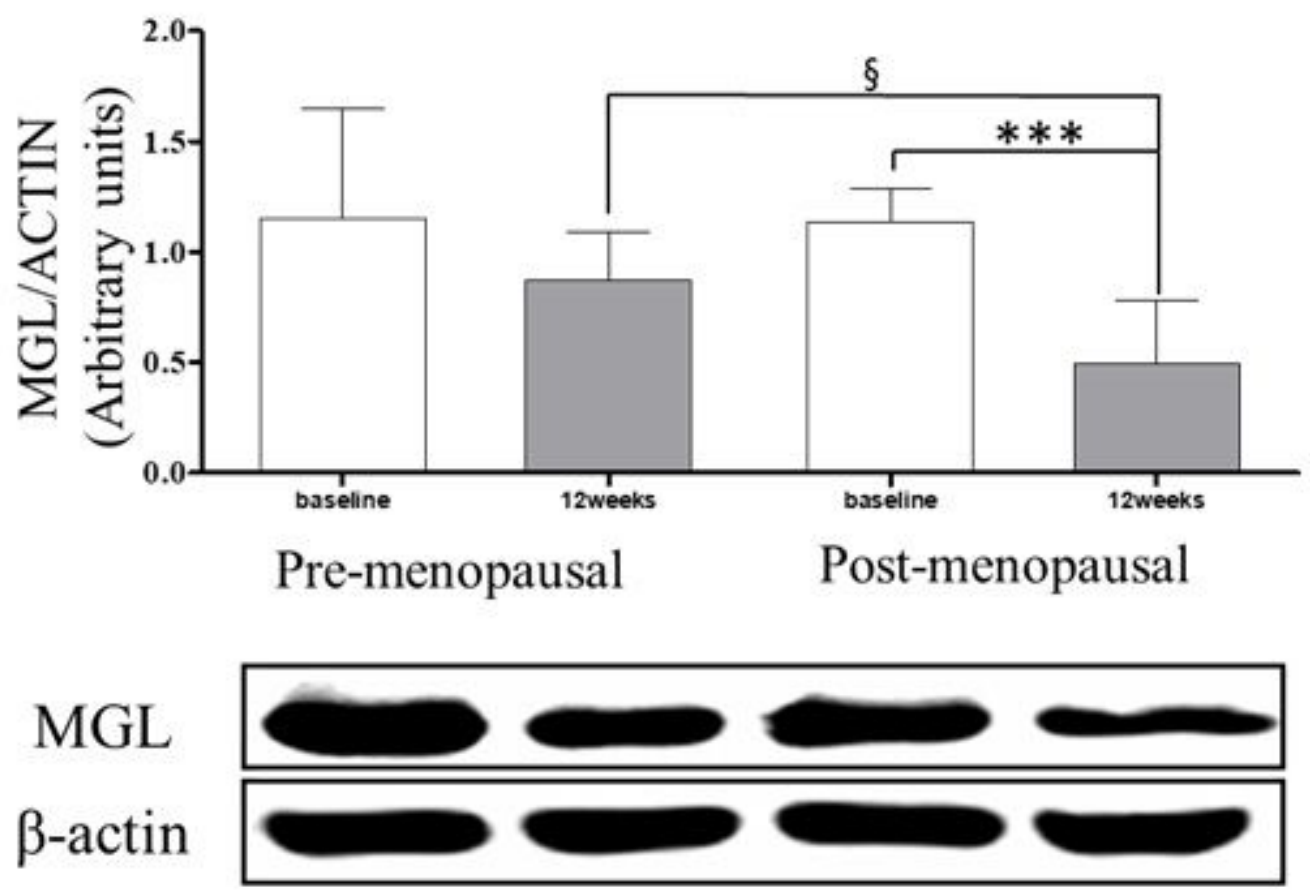

Figure 3

MGL expression baseline and after exercise 12weeks in adipose tissue $* \star \star p<0.001$, significantly different from baseline in the within group $\S p<0.05$, significantly different from 12 weeks in the each groups
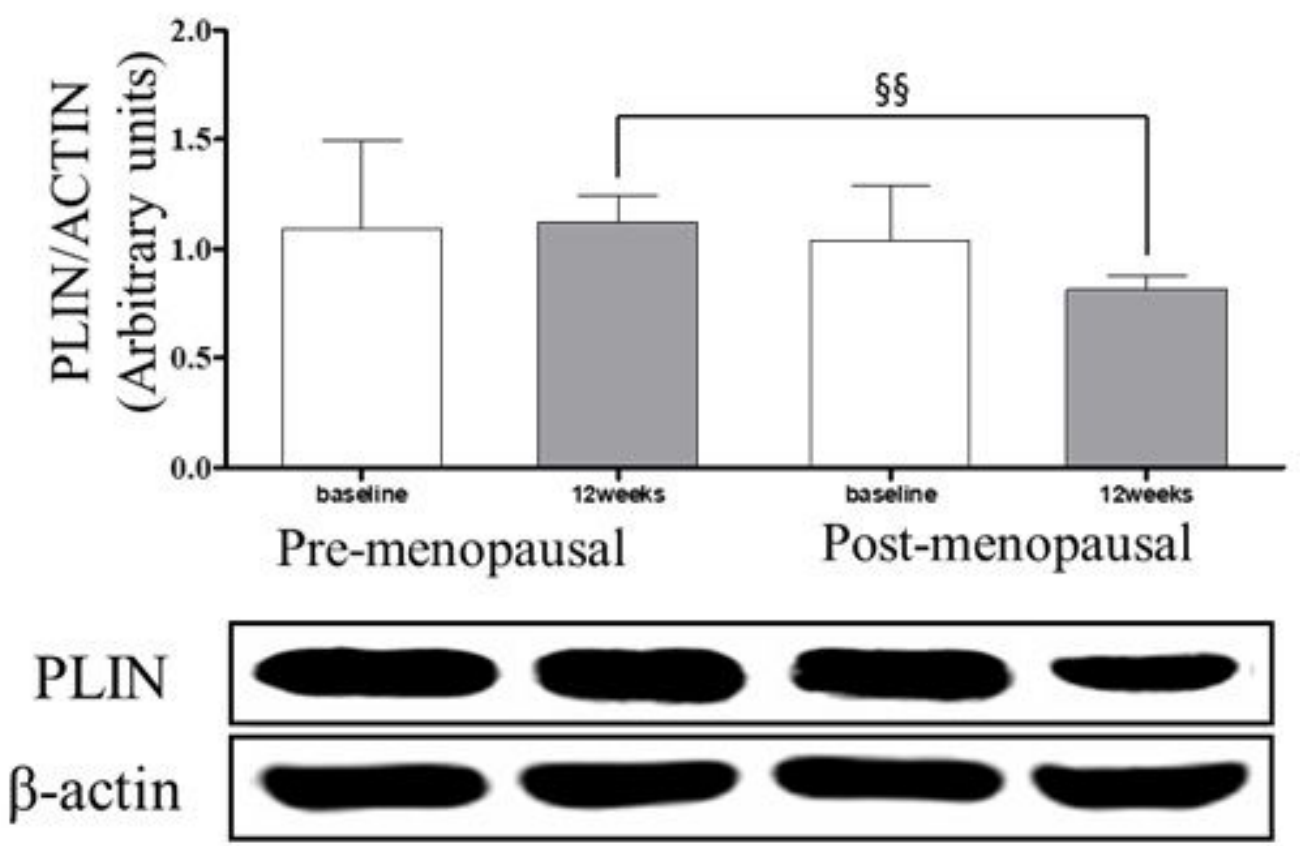

Figure 4 
PLIN expression baseline and after exercise 12weeks in adipose tissue $\S \S p<0.01$, significantly different from 12 weeks in the each groups 